\title{
LOCHKOVIAN TO PRAGIAN (LOWER DEVONIAN) NERITIC OSTRACODES FROM NIGÜELLA (ZARAGOZA, IBERIAN CHAINS, NE SPAIN)
}

\author{
Claudia DOJEN ${ }^{1}$, José Ignacio VALENZUELA- \\ RÍOS ${ }^{2}$ and Peter CARLS ${ }^{1}$
}

${ }^{1}$ Institut für Umweltgeologie; TU Braunschweig; Pockelsstr. 3; D-38106 Braunschweig, Germany; e-mail: c.dojen@tu-bs.de

${ }^{2}$ Departamento de Geología; Universitat de València; c/ Dr. Moliner, 50; E-46100 Burjassot, Spain; e-mail: Jose.I.Valenzuela@uv.es

Dojen, C., Valenzuela-Ríos, J. I. \& Carls, P. 2007. Lochkovian to Pragian (Lower Devonian) neritic Ostracodes from Nigüella (Zaragoza, Iberian Chains, NE Spain). [Ostrácodos neríticos del Lochkoviense y Praguiense (Devónico Inferior) de Nigüella (Zaragoza, Cadenas Ibéricas, NE España).] Revista Española de Paleontología, 22 (2), 105-113. ISSN 0213-6937.

\begin{abstract}
Lochkovian and Pragian ostracodes from the area of Nigüella (Iberian Chains), which is a key area for supra-regional correlation in the Early Devonian, are described for the first time. 12 ostracode taxa from the sections Ni4 and Ni2 could be identified. The silicified ostracodes of Eifelian Ecotype are low in biodiversity, have few individuals, and are comparatively poorly preserved. Characteristic taxa of the Devonian occur. Thus, the faunas show general relations to most European Early Devonian ostracode faunas. Closer relations exist to the Eastern Guadarrama. Polyzygia kroemmelbeini LeFèvre \& Weyant, 1967 and P. grekoffi Weyant, 1980 are found in the basal Pragian for the first time. Bollia bezagora Becker, 2004 is reported from the Lochkovian for the first time.
\end{abstract}

Keywords: Benthic Ostracodes, Spain, Lochkovian, Pragian, Eastern Iberian Chains, Luesma Fm., Nogueras Fm.

\section{RESUMEN}

Se describen por primera vez ostrácodos del Lochkoviense y Praguiense del área de Nigüella (Cadenas Ibéricas) que es una región importante para las correlaciones suprarregionales en el Devónico Inferior. Se identifican 12 taxones de ostrácodos en las secciones Ni4 y Ni2. Los ostrácodos silicificados pertenecen al Ecotipo Eifeliense y muestran una baja diversidad, se han encontrado pocos ejemplares que están relativamente mal conservados. Los taxones registrados son característicos del Devónico; las faunas de ostrácodos muestran relaciones con la mayoría de faunas europeas del Devónico temprano; sin embargo, las relaciones más estrechas se dan con el Guadarrama oriental. Polyzygia kroemmelbeini LeFèvre \& Weyant, 1967 y P. grekoffi Weyant, 1980 se registran por primera vez en el Praguiense basal. Asímismo, Bollia bezagora Becker, 2004 se encuentra por primera vez en el Lochkoviense.

Palabras clave: Ostrácodos bentónicos, España, Lochkoviense, Praguiense, Cordillera Ibérica Oriental, Fm. Luesma, Fm. Nogueras.

\section{INTRODUCTION}

The Lower Devonian outcrops west of the village of Nigüella (ca $55 \mathrm{~km}$ WSW of Zaragoza, Fig. 1) currently represent the northwesternmost outcrops of this age that can be attributed to the Herrera Unit of Lotze (1929, modified by Carls, 1983). Valenzuela-Ríos (1984, 1989) adequately described, for the first time, the sequence of Silurian and Lower Devonian strata that crop out in the Nigüella area. He also dated these rocks by means of brachiopods and conodonts and, by combining lithological and faunistical sequences, he was also able to identify four formations and several minor lithological units that were previously established in the southern part of the Herrera 
Unit (the so called Axial Depression of the Río Cámaras, ADRC, by Carls in 1983 and subsequent papers, updated by Carls, 1999). These formations from oldest to youngest are Bádenas Fm., Luesma Fm., Nogueras Fm. and Santa Cruz Fm. The upper limestone levels of the "Tramo 2" of the Santa Cruz Fm. that yielded Icriodus sigmoidalis Carls \& Gandl, 1969, whose attribution either to the Santa Cruz Fm. or to the Mariposas Fm. was discussed by ValenzuelaRíos (1989: 41), are now considered as the basal beds of the Mariposas Fm. (Carls \& Valenzuela-Ríos, 1998). After the pioneer work of Valenzuela-Ríos (1989) a few other works have demonstrated the palaeontological richness of the Nigüella's Lower Devonian strata and the importance of this area for palaeogeographical reconstructions (see especially, Valenzuela-Ríos \& Carls, 1996; Carls \& Valenzuela-Ríos, 1998, 1999; Valenzuela-Ríos et al., 1999; Valenzuela-Ríos \& Botella, 2000; Botella, 2005). These works have proved the position of the Nigüella area within the neritic belt of shallow water marine facies along the southwestern margin of the Cantabro-Ebroian Massif, and the importance of some fossil groups such as brachiopods, conodonts and fish remains for biostratigraphy, correlation, speciation and migration patterns (Carls \& Valenzuela-Ríos 1998, 1999; Valenzuela-Ríos et al., 1999; Botella et al., 2006). Besides, few levels have yielded poorly preserved silicified ostracodes from limestone samples etched for conodonts, some of them were previously mentioned
(Dojen et al., 2000) but not yet studied in detail. The purpose of this report is, thus, to document for the first time the ostracod fauna from two Lower Devonian sections in the Nigüella area and to analyze their stratigraphical and facies relationship to other European areas.

\section{STRATIGRAPHY}

The studied ostracodes come from the sections Ni2 and Ni4 (Figs. 2, 3) that have been described by Valenzuela-Ríos \& Botella (2000) (a more detailed description is under work by Valenzuela-Ríos \& Carls). These two sections represent together the upper third of the Luesma Fm. (units d1ca2-d1c $\gamma$; early Lochkovian) up to the upper part of the Nogueras Fm. (units d2a $\alpha 1-d 2 c \beta 1$; middle Lochkovian to mid-Pragian). In section Ni2 the Lochkovian/Pragian boundary is traced at bed 5, which corresponds to the "Leitbank A", a marker bed containing the entry of Vandercammenina sollei Carls, 1986, the index brachiopod for the beginning of the Pragian in the Rhenish Facies.

Section Ni4 includes parts of the uppermost member of the Luesma Fm. (d1c), which in this section measures about $116 \mathrm{~m}$, and parts of the lowermost member of the Nogueras Fm. (d2a) (48 m exposed). The lowermost 70 $\mathrm{m}$ of Ni4 belong to submember d1c $\alpha$ (incomplete; levels 1-5), and corresponds to the dark shales and the subse-

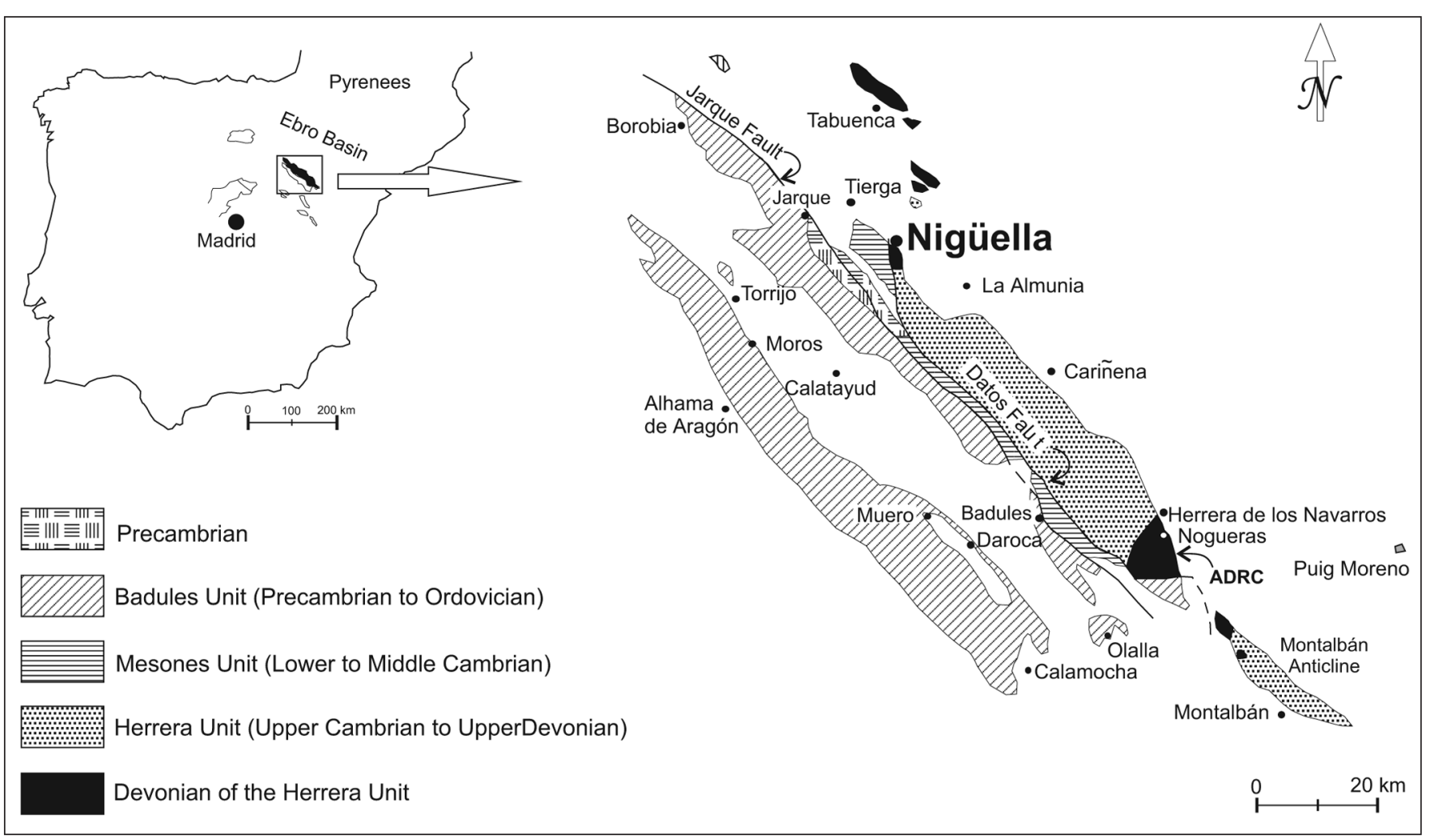

Figure 1. Location of the Nigüella outcrops area within the Palaeozoic of the Iberian Chains (modified from Gozalo et al., 2001). 
quent white orthoquarzites with intercalated calcareous lenses (in decimeters) from the ADRC that furnished brachiopods and conodonts (Carls \& Valenzuela-Ríos, 1999: 284). According to these authors the stratigraphical succession and the presence of the brachiopod Hollardina plana Racheboeuf, Carls \& García-Alcalde, 1981 (level 5) allows the recognition of unit d1ca2 approximately 44

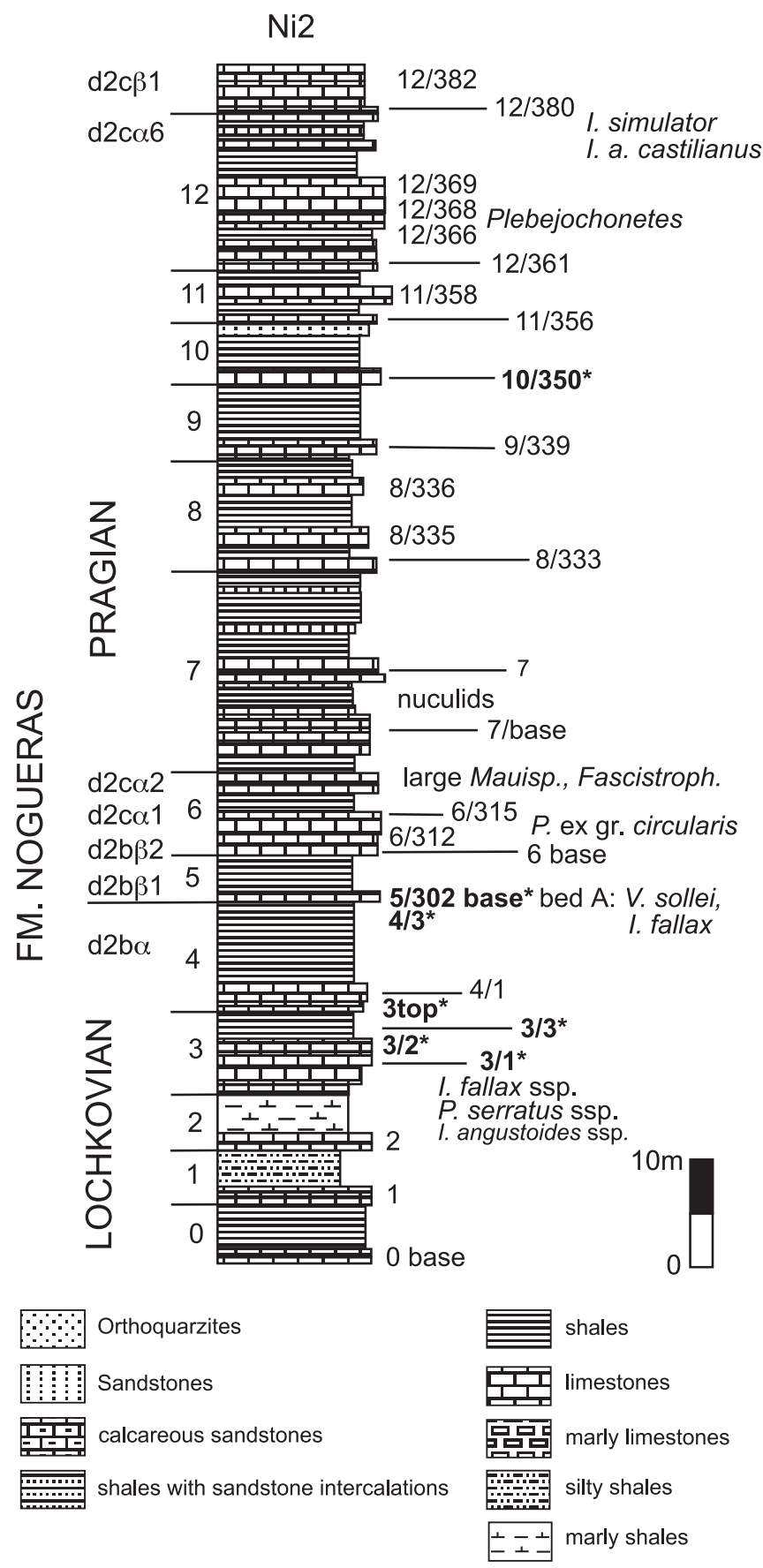

Figure 2. Stratigraphical column of the section Ni2 (based on Valenzuela-Ríos \& Botella, 2000: fig. 2); relevant (index) fossils and conodont samples are indicated; ostracode bearing samples are marked with an asterisk. $\mathrm{m}$ above the beginning of the exposed section. First ostracodes occur in levels 3 and 4. Submember d1c $\beta$ (level 6) consist of about $12 \mathrm{~m}$ of orthoquarzites with shale intercalations. Submember d1c $\gamma$ is about $28 \mathrm{~m}$ thick and consists of an alternation of shales, lenticular calcareous levels, and bioturbated sand beds. At the top (levels 8 and 9) more limestone beds occur. The transition to the Nogue-

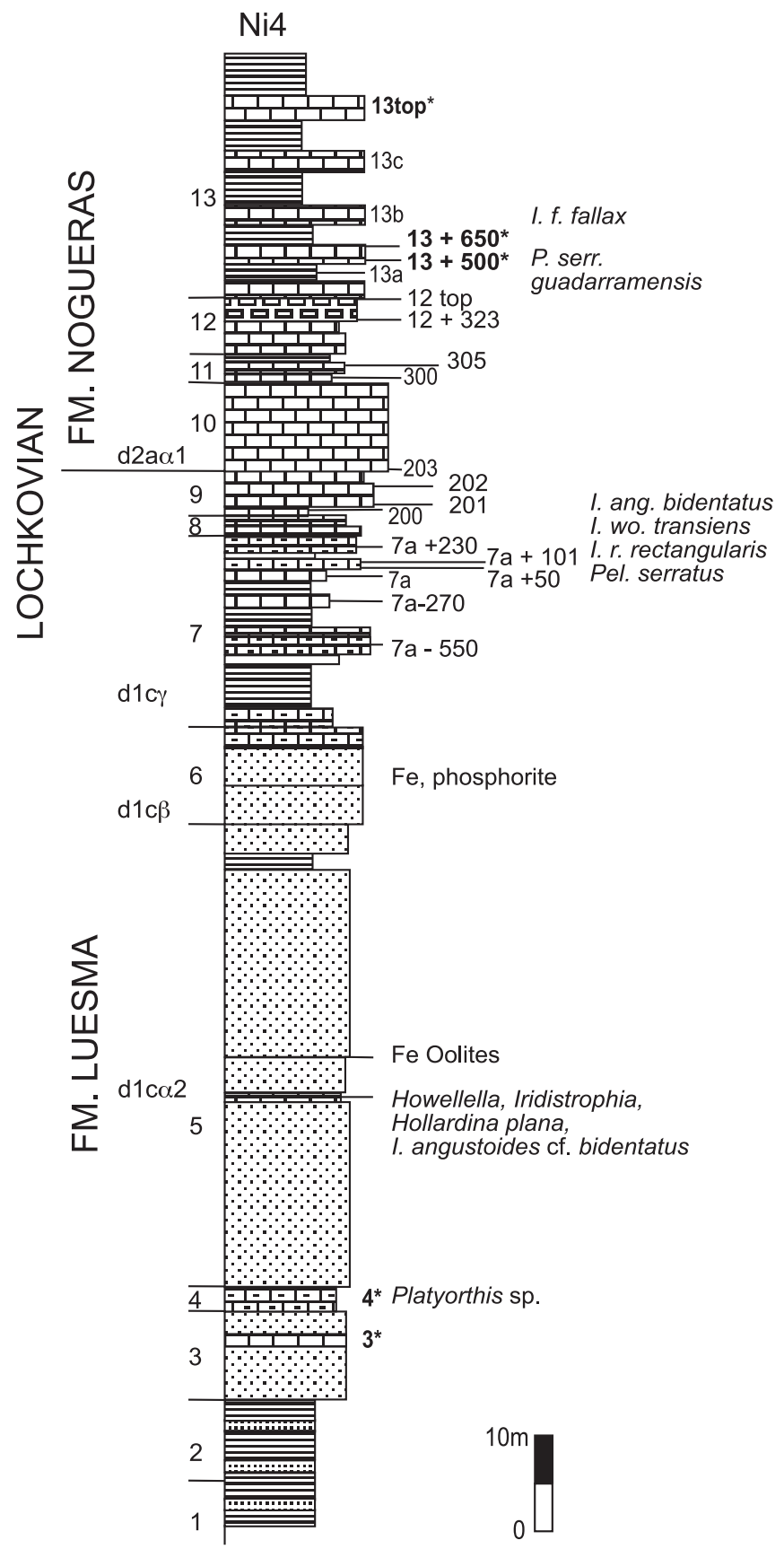

Figure 3. Stratigraphical column of the sections Ni4 (based on Valenzuela-Ríos \& Botella, 2000: fig. 2); relevant (index) fossils and conodont samples are indicated; ostracode bearing samples are marked in bold with an asterisk. Legend as for figure 2 . 
ras Fm. (d2) is well recognizable through the massive 9.8 $\mathrm{m}$ dark red limestone (level 10) with abundant bryozoans and scarce shale interbeds at the base of the Nogueras Fm. The massive limestones are followed by $38 \mathrm{~m}$ of alternations of limestone beds and shale levels, which are dominant in the uppermost $27 \mathrm{~m}$. Only the lower parts of member $\mathrm{d} 2 \mathrm{a}$ are exposed; the entire thickness of the member in Ni4 is unknown.

The Nogueras Fm. is partly exposed in the Ni2 section, ranging from the upper part of member $\mathrm{d} 2 \mathrm{a}$ up to the lower part of d2c. The exposed part of member d2a measures about $16 \mathrm{~m}$; shales dominate with a few shelly limestone beds, occasionally with abundant phosphorite. Member d2b is composed of around $25 \mathrm{~m}$ of, mainly, sandstones with shales and few shelly limestones, phosphate pebbles abundant in some levels and includes the Lochkovian/Pragian boundary. This boundary in Ni2 is traced in the upper part of the $60 \mathrm{~cm}$ thick limestone bed 5, which corresponds to the marker bed "Leitbank A" with the brachiopod Vandercammenina sollei. Member $\mathrm{d} 2 \mathrm{c}$ is incompletely exposed and measures about $71 \mathrm{~m}$, the lower $67 \mathrm{~m}$ correspond to submember $\mathrm{d} 2 \mathrm{c} \alpha$. The submember is mainly built up by alternations of limestones, some of them with algal lamination, and shales with palaeochannels of sandstones that are more abundant in the upper half; it begins with a group of limestone beds containing the brachiopod Platyorthis ex gr. circularis (Sowerby, 1842). From here upwards the palaeontological (mainly brachiopods) and lithological se- quence permits the recognition of the detailed subdivision established in the ADRC and allows a thorough correlation of this part of the sequence (including individual centimetric beds) between the ADRC and Nigüella (Carls \& Valenzuela-Ríos, 1999). Just above the entry of the conodont I. simulator Carls, 1969 , submember d2c $\beta$ starts, but only its lowermost $4 \mathrm{~m}$ are exposed. These $4 \mathrm{~m}$ of shelly marly limestones beds with shales interbedded yielded a variety of shelly fauna together with conodonts. Also an important lithological change (end of the siliciclastic supply, which are abundant in the upper part of the submember $\mathrm{d} 2 \mathrm{c} \alpha$ ) took place. Both, lithological and palaeontological, changes that are observed in several localities of Spain and France are interpreted as the beginning of a trangressive pulse in Ibero-Armorica (Carls \& Valenzuela-Ríos, 1999; Valenzuela-Ríos \& Carls, 1996).

\section{SYSTEMATIC PALAEONTOLOGY}

The present material is comparatively poorly preserved. Only a few well known species could be identified, but often only open nomenclature was appropriate; therefore, no complete systematic description is presented. Smooth ostracode valves are mentioned in the range table only (Tab. 1). The occurrences in other regions refer to the biostratigraphical subdivision of Celtiberia, as this is the most detailed one for the early Devonian. Dojen (2005)

\begin{tabular}{|c|c|c|c|c|c|c|c|c|c|c|c|c|c|}
\hline & $\begin{array}{l}\stackrel{n}{\gamma} \\
z\end{array}$ & $\begin{array}{l}\stackrel{+}{\partial} \\
\dot{Z}\end{array}$ & $\begin{array}{l}+ \\
\stackrel{m}{7} \\
\dot{\gamma}\end{array}$ & 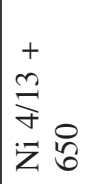 & 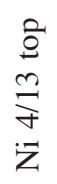 & $\begin{array}{l}\vec{⿱} \\
\vec{\lambda} \\
\vec{z}\end{array}$ & $\begin{array}{l}\frac{N}{m} \\
\stackrel{n}{z} \\
i \bar{z}\end{array}$ & 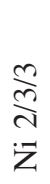 & $\begin{array}{l}\stackrel{0}{0} \\
\stackrel{2}{a} \\
i \\
z\end{array}$ & $\begin{array}{l}\stackrel{m}{\stackrel{N}{d}} \\
\stackrel{z}{z}\end{array}$ & $\begin{array}{l}\delta \\
\stackrel{n}{\Omega} \\
\stackrel{n}{\lambda} \\
z \\
z\end{array}$ & 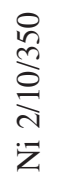 & $\begin{array}{l}\stackrel{\jmath}{i} \\
i \bar{z}\end{array}$ \\
\hline Bollia bezagora & & & & & & & & & 2 & & 2 & & \\
\hline Bollia sp. & & & & & & & & 1 & 5 & 2 & 10 & & \\
\hline Ulrichia sp. & 2 & & 1 & & & & & & & & & & \\
\hline Poloniella sp. & & & 1 & 2 & 4 & 3 & 2 & & & & & & 1 \\
\hline Polyzygia kroemmelbeini & & & & & & & & & & & 2 & & \\
\hline P. grekoffi & & & & & & & & & & & 1 & & \\
\hline Polyzygia sp. & & 3 & & & & & & 1 & & 1 & & 2 & \\
\hline Ponderodictya? sp. & & & & & & & & & & & 2 & 17 & \\
\hline Leptoprimitia velillana & & & & & & & & & & & 2 & & \\
\hline Leptoprimitia aff. velillana & & & & & & & & & & & 1 & & \\
\hline Leptoprimitia sp. & & & & & & & & & & & 10 & & \\
\hline Eridoconcha sp. & & & & & & & & & & & 10 & & \\
\hline smooth valves & & & & & & & & & & & 21 & 3 & \\
\hline & \multicolumn{5}{|c|}{ Lochkovian } & \multicolumn{5}{|c|}{ Lochkovian } & \multicolumn{3}{|c|}{ Pragian } \\
\hline
\end{tabular}

Table 1. Distribution of ostracodes from the sections Ni4 and Ni2. 
correlates the European ostracode record with Celtiberia. The material is stored at the Museo de Geología de la Universitat de València under the catalogue numbers MGUV 5900 - 5932.

Abbreviations: C: carapace(s); LV: left valve(s); RV: right valve(s); Stk: steinkern(s).

Notations: For referring the position of the samples the following notation has been used: section/bed/sample (when several samples from the same bed have been taken); for instance Ni2/5/302 means sample 302 from bed 5 of section Ni2. From some ostracodes only siliceous coats are preserved that are called "siliceous incrustations".

Class OSTRACODA Latreille, 1802

Genus Bollia Jones \& Holl, 1886

\section{Bollia bezagora Becker, 2004}

Fig. 4d

\footnotetext{
* 2004 Bollia bezagora n. sp. - Becker in Becker et al., 27-28.

v 2005 Bollia bezagora - Dojen, 73-76, text-fig. 8.188.21; pl. 4, figs. 5-6 [with further synonymy].
}

Material: 2 silicified LV from Ni2/3 top (MGUV 5900); 2 silicified LV from Ni2/5/302 (MGUV 5901, 5902).

Remarks: Due to the comparatively narrow furrow and the uniformly broad L1 and L2 the material is assigned to $B$. bezagora, although $\mathrm{S} 2$ is distinctly bent. This is the oldest record of this species.

Occurrences: Nogueras Fm. (submember d2ba; late Lochkovian), Nigüella, Aragón, Spain; Nogueras Fm., Sta. Cruz Fm., and Mariposas Fm. (units d2c $\beta 1$ to base of d4aa; Pragian), ADRC, Aragón, Spain; LaVid Fm. and Santa Lucía Fm. (equivalent to the interval from d3by to Monforte Fm.; late Pragian to early Eifelian), León, Spain; St. Céneré Fm., beds 49-61 (equivalent to d2b $\beta 2$ up to d2ca; early Pragian), Armorica, France; Tentakuliten-Schiefer, horizon III (equivalent to middle to upper parts of $d 4 b \beta$; early Late Emsian), Thuringia, Germany; Oui-n-Mesdoûr Fm. ("unit 21", equivalent to the lower parts of submember d4ba; Early Emsian), SW Anti Atlas, Morocco; "Marhouma-kilomètre 29" (probably "Emsian médiane" and "Eifélien supérieur"), Ougarta, Algeria.

\section{Bollia sp.}

Material: 1 specimen from Ni2/3/3 (MGUV 5903); 5 specimens from Ni2/3 top (MGUV 5904); 2 specimens from Ni2/4/3 (MGUV 5906); 10 specimens from Ni2/5/302 (MGUV 5905).
Genus Ulrichia Jones, 1890

\section{Ulrichia sp.}

Fig. 4c

Material: 2 silicified fragments from Ni4/3 (MGUV 5907); 1 Stk. from Ni4/13+500 (MGUV 5929).

Remarks: The material could be identified on genus level only, but seems to belong to the subgenus Ulrichia (Subulrichia) Abushik, 1971.

Genus Poloniella Gürich, 1896

\section{Poloniella sp.}

Figs. $4 \mathrm{a}-4 \mathrm{~b}$

Material: 1 Stk. from Ni4/13+500 (MGUV 5931); 2 Stks from Ni4/13+650 (MGUV 5912, 5930); 4 Stks from Ni4/13 top (MGUV 5913); 3 Stks from Ni2/3/1 (MGUV 5908); 2 Stks from Ni2/3/2 (MGUV 5909, 5910); 1 silicified LV from Ni2/12 (MGUV 5911).

Genus Polyzygia Gürich, 1896

\section{Polyzygia kroemmelbeini LeFèvre \& Weyant, 1967}

Fig. $4 \mathrm{f}$

* 1967 Polyzygia kroemmelbeini n. sp. - LeFèvre \& Weyant (in Weyant), 124-126, pls. 3, figs. 4-6, pl. 5 , fig. 3 .

v 2005 Polyzygia kroemmelbeini - Dojen, 143-145; text-figs. 8.89-8.91, pl. 12, figs. 6-12 [with further synonymy].

Material: 2 silicified RV from Ni2/5/302 (MGUV 5914, 5915).

Remarks: This is the first record of $P$. kroemmelbeini from the basal bed of the Pragian. The figured specimen seems to have a rather bulbous $\mathrm{L} 4$, which reminds on $P$. normannica Weyant, 1967, but L3 is not connected with the inner ridge.

Occurrences: Nogueras Fm. (d2b $\beta 1$; basal Pragian), Nigüella, Aragón, Spain; Nogueras Fm. up to Mariposas Fm. (units d2c $\beta 1$ to d4b $\alpha$; early mid-Pragian to late Early Emsian), ADRC, Aragón, Spain; l'Armorique Fm. and Nehou Fm. (Pragian; equivalents of submember d2c $\beta$ ), Armorica, France; La Ladrona Fm. (Early Emsian; equivalent to the interval from d $4 a \alpha$ to lower parts of $d 4 b \beta$ ), Aguión Fm. (early Late Emsian; equivalent to the interval from amid $\mathrm{d} 4 \mathrm{~b} \beta$ to $\mathrm{d} 4 \mathrm{~b} \varepsilon$ ) and Moniello Fm. (Late Emsian; equivalent to the interval Castellar Fm. to Molino Fm.), Asturias, Spain; LaVid Fm., units 2 and 3 (late Pragian to Early Emsian; equivalent to the interval from $\mathrm{d} 3 \mathrm{~b} \gamma \mathrm{y}$ up to amid $\mathrm{d} 4 \mathrm{~b} \beta$ ) and Sta. Lucía Fm. (Late Emsian; equivalent to the 
a

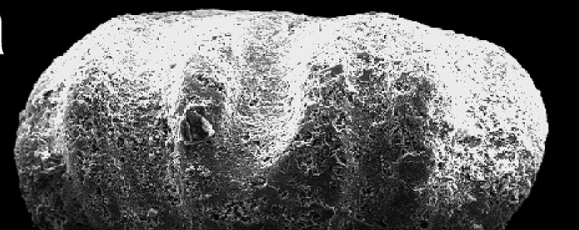

d

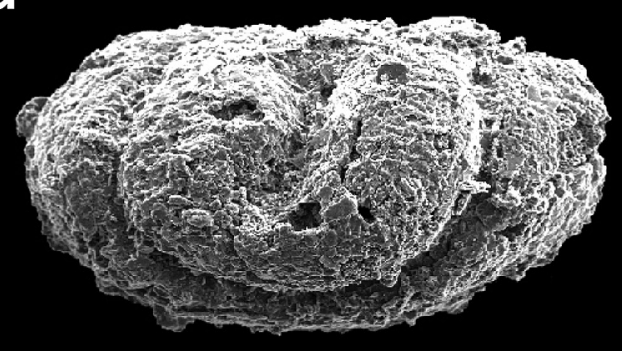

5

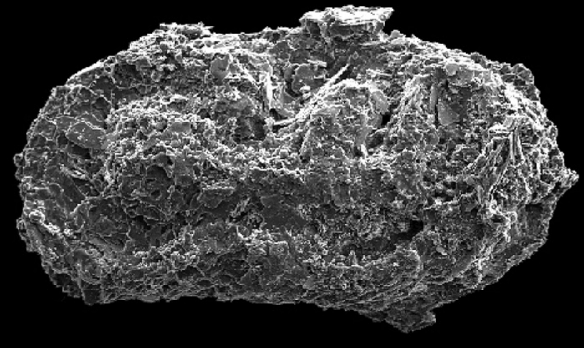

h

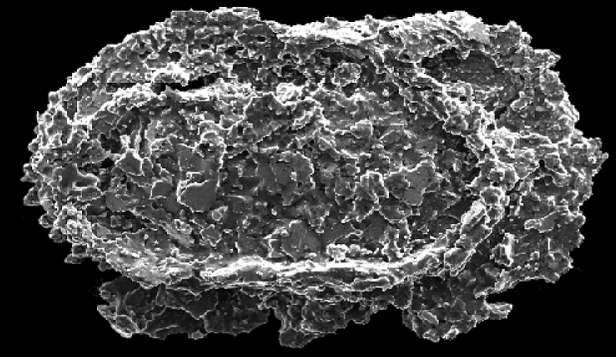

j1

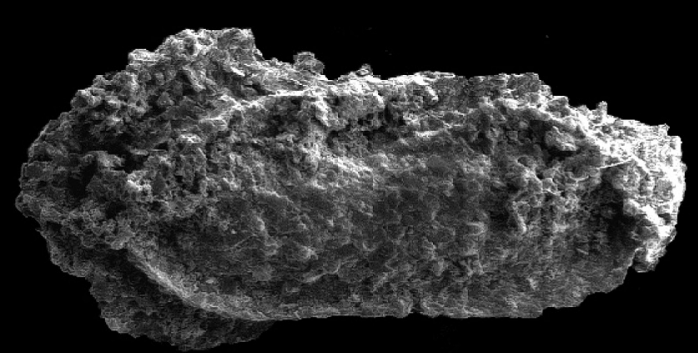

b

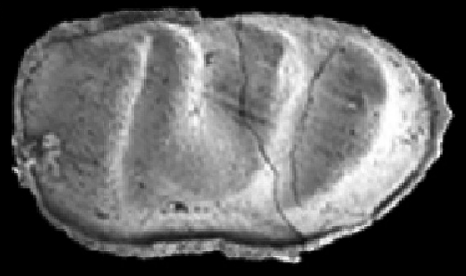

C
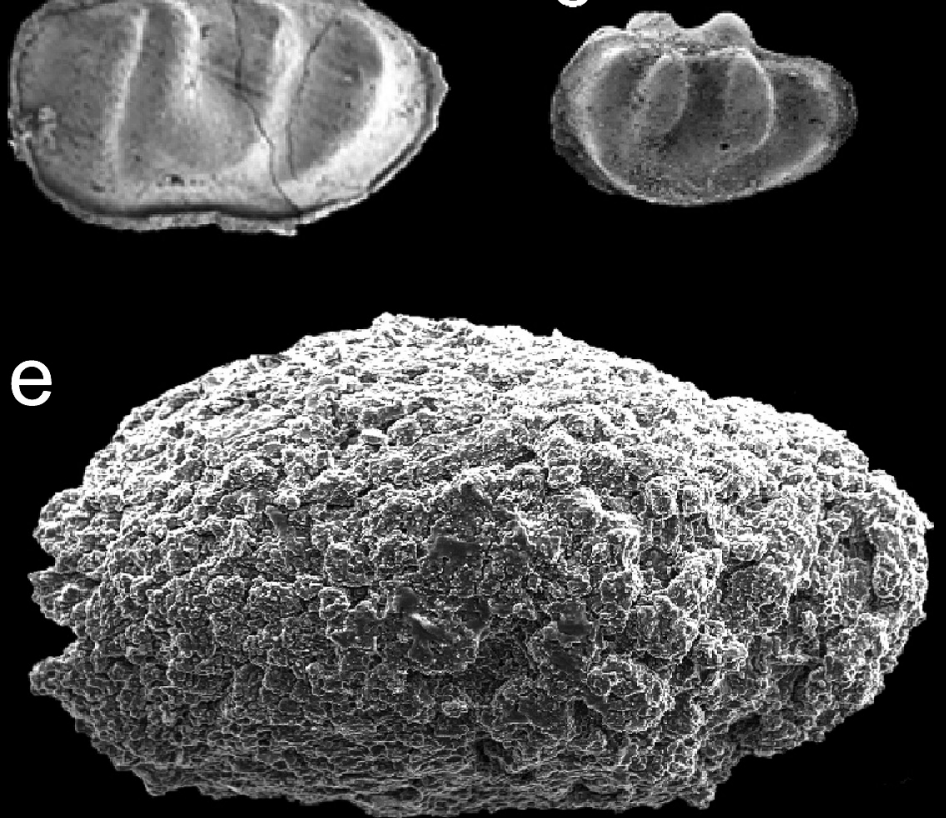

g

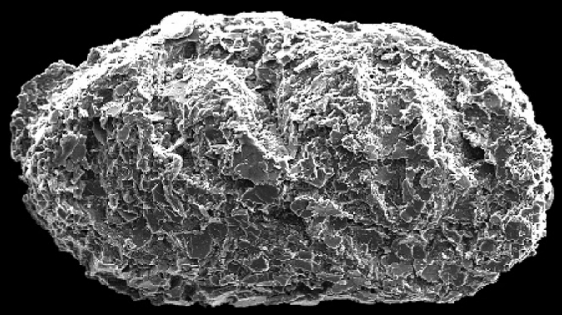

i

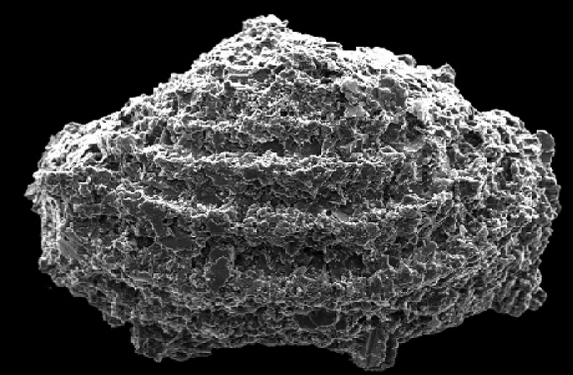

j2

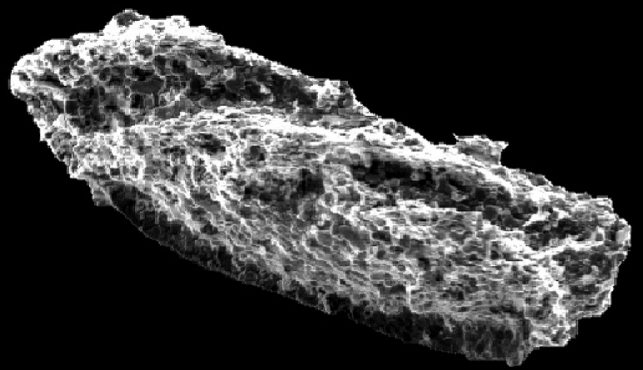

Figure 4. a-b, Poloniella sp.; a, phosphatic Stk. of a carapace from Ni2/3/2 (MGUV 5909), exterior lateral view of left valve (?), 1: $0.73 \mathrm{~mm}$; b, Stk. of a carapace from Ni4/13 +650 (MGUV 5930), exterior lateral view of right valve, $1: 0.62 \mathrm{~mm}$. c, $U l$ richia sp., Stk. of a carapace from Ni4/13 +500 (MGUV 5929), oblique exterior lateral view of left valve, 1: $0.45 \mathrm{~mm}$. d, Bollia bezagora Becker, 2004, silicified left valve from sample Ni2/5/302 (MGUV 5901), exterior lateral view, $1: 0.81 \mathrm{~mm}$. e, Ponderodictya? sp., right valve (?) from sample Ni2/10/350 (MGUV 5921), exterior lateral view, 1: 1.27 mm. f, Polyzygia kroemmelbeini LeFèvre \& Weyant, 1967, silicified right valve from sample Ni2/5/302 (MGUV 5914), exterior lateral 
interval Castellar Fm. to Molino Fm.), León, Spain; Dkhissa Fm. (Siegenian) and Teferguenit Fm. (Early Emsian), Beni Abbés, Saoura, Algeria; Oui-n-Mesdoûr Fm. and Khebchia Fm. (Early to Late Emsian), Anti Atlas, Morocco; Grzegorzowice Fm. (latest Emsian to early Eifelian), Holy Cross Mts., Poland.

\section{Polyzygia grekoffi Weyant, 1980}

Fig. $4 \mathrm{~g}$

* 1980 Polyzygia grekoffi n. sp. - Weyant, 281, pl. 37, fig. 1-3, 5, 6, 8.

v 2005 Polyzygia grekoffi - Dojen, 145-146, text-figs. 8.92-8.94, pl. 12, figs. 13-17 [with further synonymy].

Material: 1 silicified LV from Ni2/5/302 (MGUV 5917).

Remarks: This is the first record of $P$. grekoffi from the basal bed of the Pragian.

Occurrences: Nogueras Fm. (d2b $\beta 1$; basal Pragian), Nigüella, Aragón, Spain; Nogueras Fm. up to Mariposas Fm. (units d2c $\beta$ to d4a $\gamma$; mid-Pragian to Early Emsian), Aragón, Spain; l'Armorique Fm. and Nehou Fm. (mid-Pragian; equivalents of submember d2c $\beta$ ), Armorica, France; LaVid Fm. (late Pragian to Early Emsian), León, Spain; Khebchia Fm. (Late Emsian), Morocco; Hobräcker Schichten (Eifelian), Rhenish Slate Mts., Germany. Probably also in the Polentinos Fm. (Late Emsian to early Eifelian) and Gustalapiedra Fm. (late Eifelian), Palencia, Spain.

\section{Polyzygia sp.}

Material: 3 siliceous incrustations from Ni4/4 (MGUV 5920); 1 siliceous incrustation from Ni2/3/3 (MGUV 5918); 1 siliceous incrustation of a LV from Ni2/4/3 (MGUV 5916); 2 silicified valves from Ni2/10/350 (MGUV 5919).

Genus Ponderodictya Coryell \& Malkin,1936

\section{Ponderodictya? sp.}

Fig. $4 \mathrm{e}$

Material: 2 valves from Ni2/5/302 (5922); 17 valves from Ni2/10/350 (MGUV 5921, MGUV 5923).
Remarks: There are several poorly preserved suboval thick valves, which may belong to the genus.

Genus Leptoprimitia Kummerow, 1953

\section{Leptoprimitia velillana Dojen, 2005}

Fig. $4 \mathrm{~h}$

* 2005 Leptoprimitia velillana n. sp. - Dojen, 178-179, text-figs. 8.125-8.126, pl. 16, figs. 1-10.

Material: $1 \mathrm{RV}$ and $1 \mathrm{LV}$ from Ni2/5/302 (MGUV 5924, 5925).

Remarks: Despite of the poor preservation the distinct spiral-like extramarginal ridge allows the identification of the species.

Occurrences: Nogueras Fm. (d2b $\beta 1$, basal Pragian), Nigüella, Aragón, Spain; Cercadillo Fm. (member MS4; Middle Lochkovian; equivalent to units d2a 23 to d2a 44 in Aragón), Eastern Guadarrama, Spain.

Leptoprimitia aff. velillana Dojen, 2005 Fig. $4 \mathrm{j}$

Material: 1 LV from Ni2/5/302 (MGUV 5932).

Remarks: The valve is very similar to $L$. velillana, but is more elongated and has a distinct muscle spot. Thus, it resembles L. cabrierensis Groos-Uffenorde, 1979 but the marginal ridge is not interrupted and it is posterodorsally connected with the marginal flange.

Occurrence: Nogueras Fm. (d2b $\beta 1$, basal Pragian), Nigüella, Aragón, Spain.

\section{Leptoprimitia sp.}

Material: 1 valve and 9 fragments from Ni 2/5/302 (MGUV 5926).

Remarks: The material may belong to $L$ velillana, but due to the poor preservation, a more precise identification is not possible.

view, 1: 0.77 mm. g, Polyzygia grekoffi Weyant, 1980, silicified left valve from sample Ni2/5/302 (MGUV 5917), exterior lateral view, 1: $0.74 \mathrm{~mm}$. h, Leptoprimitia velillana Dojen, 2005, silicified right valve from sample Ni2/5/302 (MGUV 5924), exterior lateral view, 1: 0.80 mm. i, Eridoconcha sp., silicified left valve (?) from sample Ni2/5/302 (MGUV 5927), exterior lateral view, 1: $0.73 \mathrm{~mm}$. j, Leptoprimitia aff. velillana Dojen, 2005, silicified left valve from sample Ni2/5/302 (MGUV 5932); j1, exterior lateral view; j2, oblique dorsal view; 1: 0.92mm (including marginal ridge). All x 75, except for j2). 
Genus Eridoconcha Ulrich \& Bassler, 1923

\section{Eridoconcha sp.}

Fig. $4 \mathrm{i}$

Material: 10 silicified specimens from Ni 2/5/302 (MGUV 5927, 5928).

Remarks: Due to the poor preservation no identification on species level was possible.

\section{DISCUSSION OF THE OSTRACODE FAUNAS}

The ostracodes from Nigüella belong to the Eifelian Ecotype sensu Becker (in Bandel \& Becker, 1975) indicating shallow water marine environments. The faunas consist mainly of characteristic Devonian taxa like Ulrichia and Poloniella. Polyzygia is restricted to the Devonian of Central Europe, North Africa and the Russian Platform. Both $P$. kroemmelbeini and $P$. grekoffi have their acme in the Pragian and Emsian (cf. Groos-Uffenorde et al., 2000) and have now their oldest record at Nigüella, in the very basal bed of the Pragian (marker bed A), confirming the suggestion of Crasquin-Soleau et al. (1994: fig. 3). Bollia bezagora is only known from the Devonian of Europe and North Africa and has its acme also in the Pragian and Emsian. At Nigüella it occurs in submember d2ba (late Lochkovian), which currently represents its oldest record worldwide.

The low ostracodes biodiversity and the presence of mainly characteristic wide spread taxa show general relations to any European Early Devonian marine shallow water ostracode faunas like those of the ADRC (Dojen, 2005), Cantabrian Mountains (e.g. Becker, 2001), Armorica (e.g. Weyant, 1980), or Thuringia (e.g. Zagora, 1968). Closer relations exist to the nearby Eastern Guadarrama through Leptoprimitia velillana that has at Nigüella its first record outside its type locality. This record extends its range from the Middle Lochkovian to the basal Pragian (equivalents of $\mathrm{d} 2 \mathrm{a} \alpha 3$ to $\mathrm{d} 2 \mathrm{~b} \beta$ ). In both areas, L. velillana is associated with similar ostracode taxa, although in the Eastern Guadarrama it has a mass occurrence in a sample together with elements of middle Lochkovian Hercynic Biofacies [Homoctenowakia senex, Ancyrodelloides transitans (Bischoff \& Sannemann, 1958)], whereas at Nigüella only two specimens were found which are associated with more shallow water taxa of basal Pragian age (Icriodus fallax Carls, 1975, Icr. angustoides alcoleae Carls, 1969, and Vandercammenina sollei Carls, 1986). Possibly, L. velillana preferred comparatively clear water.

\section{ACKNOWLEDGEMENTS}

This work represents a contribution to IGCP 499 Devonian land-sea interaction: evolution of ecosystems and climate. The
Alexander von Humboldt-Stiftung partially supported J.I. V-R. Luis Carlos Sánchez de Posada (Oviedo) and Helga Uffenorde (Göttingen) provided thoughtful comments that helped to improve the manuscript; we thank both for their time and effort.

\section{REFERENCES}

Abushik, A. F. 1971. Ostracoda from the Silurian-Lower Devonian key section of Podolia. In: Palaeozoic Ostracoda from the key sections in the European part of the USSR (Ed. V. A. Ivanova). Izd. "Nauka", 7-133.

Bandel, K. \& Becker, G. 1975. Ostracoden aus paläozoischen pelagischen Kalken der Karnischen Alpen (Silurium bis Unterkarbon). Senckenbergiana lethaea, 56, 1-83.

Becker, G. 2001. Fazies-anzeigende Ostracoden-Faunen aus der Santa Lucía Formation (Unterdevon, Oberemsium) von Asturien und N León (N-Spanien). Palaeontographica, Abteilung A, 263, 1-136.

Becker, G., Lazreq, N. \& Weddige, K. 2004. Ostracods of Thuringian provenance from the Devonian of Morocco. Paleontographica, A, 271, 1-109.

Botella, H. 2005. Microictiolitos del Devónico Inferior de Nigüella (Cordillera Ibérica), consideraciones paleobiológicas e hidrodinámicas de condrictios y agnatos primitivos. Tesis Doctoral, Universitat de València, 258 pp. (inédita).

Botella, H., Valenzuela-Ríos, J. I. \& Carls, P. 2006. A new Early Devonian Thelodont from Celtiberia (Spain); with revision of Spanish Thelodonts. Palaeontology, 49, 115.

Carls, P. 1983. La Zona Asturoccidental-leonesa en Aragón y el Macizo del Ebro como prolongación del Macizo Cantábrico. Libro Jubilar J.M. Ríos, Instituto Geológico y Minero de España, III, 11-32.

Carls, P. 1999. El Devónico de Celtiberia y sus fósiles. In: VI Jornadas Aragonesas de Paleontología; 25 años de Paleontología Aragonesa Homenaje al profesor Leandro Sequeiros (Eds. J.A. Gámez Vintanez \& E. Liñán). Institución Fernando el Católico, Zaragoza, 101-164.

Carls, P. \& Valenzuela-Ríos, J. I. 1998. The ancestry of the Rhenish Middle Siegenian Brachiopod fauna in the Iberian Chains and its palaeozoogeography (Early Devonian). Revista Española de Paleontología, $\mathbf{n}^{\circ}$ extr. Homenaje al Prof. Gonzalo Vidal, 123-142.

Carls, P. \& Valenzuela-Ríos, J. I. 1999. Similitudes y diferencias estratigráficas entre el Pridoliense-Praguiense celtibérico y armoricano. Revista Española de Paleontología, 14, 279-292.

Coryell, H.N. \& Malkin, D.S. 1936. Some Hamilton Ostracodes from Arkona, Ontario. American Museum Novitates, 891, 1-20.

Crasquin-Soleau, S., Lethiers, F. \& Tassy, P. 1994. Évolution des espèces du genre Polyzygia (Ostracoda, Dévonien). Compte Rendus de l'Académie de Sciences, 319 (2), 365-371.

Dojen, C. 2005. Early Devonian ostracods of Celtiberia (NE Spain)-taxonomy, palaeoecology, biostratigraphy, and 
biogeography. Electronic edition, Braunschweig, Technische Universität, Dissertation, 2005: XIX, 256, [LIII] p.; <HTTP://OPUS.TU-BS.DE/OPUS/VOLLTEXTE/2005/815>

Dojen, C., Valenzuela-Ríos, J. I. \& Carls, P. 2000. Nota preliminary sobre los ostrácodos del Lochkoviense y Praguiense (Devónico Inferior) de Nigüella (Zaragoza, Cadenas Ibéricas). I Congreso Ibérico de Paleontología, 208-209.

Groos-Uffenorde, H. 1979. Die Ostrakoden-Fauna. In: Die "Calcaires à polypiers siliceux" und ihre Ostracoden-Faunen (Oberes Unter-Devon; Montagne Noire, S-Frankreich) (Coord. R. Feist \& H. Groos-Uffenorde). Senckenbergiana lethaea, 60, 83-187.

Groos-Uffenorde, H., Lethiers, F. \& Blumenstengel, H. 2000. Ostracodes and Devonian Stratigraphy. Courier Forschungsinstitut Senckenberg, 220, 99-111.

Gozalo, R., Carls, P., Valenzuela Ríos, J. I. \& Pardo Alonso, M. V. 2001. El Devónico Superior de Tabuenca (provincia de Zaragoza). In: La era Paleozoica. El desarrollo de la vida marina. Homenaje al Profesor Jaime Truyols (Eds. J. A. Gámez Vintaned \& E. Liñán). Institución Fernando El Católico, Zaragoza, 169-190.

Gürich, G. 1896. Das Palaeozoikum im Polnischen Mittelgebirge. Verhandlungen der russischen kaiserlichen mineralogischen Gesellschaft, serie 2, 32, 1-539.

Jones, T.R. 1890. On some Devonian and Silurian Ostracoda from North America, France, and the Bosphorus. Quarterly Journal of the Geological Society of London, 46, 534-556.

Jones, T.R \& Holl, H.B. 1886. Notes on the palaeozoic bivalved Entomostraca - 21: on the genus Beyrichia and some new species. Annals and magazine of natural history, series 5, 17 (100), 337-363.

Kummerow, E. 1953. Über oberkarbonische und devonische Ostracoden in Deutschland und in der Volksrepublik Polen. Geologie, Beihefte, 7, 1-75.

Latreille, P.A. 1802. Histoire naturelle, générale et particulière des Crustacés et des Insectes. vol. 3. F. Dufart, Paris, IXII, 13-468.

Lotze, F. 1929. Stratigraphie und Tektonik des keltiberischen Grundgebirges (Spanien). Abhandlungen der Gesellschaft der Wissenschaften zu Göttingen, Mathematisch-Physikalische Klasse, Neue Folge, 14 (1-13), 1-320.

Ulrich, E.O. \& Bassler R.S. 1923. Paleozoic Ostracoda: their morphology, classification and occurrence. Maryland Geological Survey, reports, 9 (Silurian), 271-391, 500704, 747-776.

Valenzuela-Ríos, J.I. 1984. Estudio geológico de un sector de las Cadenas Ibéricas Orientales entre Minas Tierga, Mesones y Nigüella (Zatagoza). Tesis de Licenciatura, Universidad de Zaragoza, 132 pp. (inédita)

Valenzuela-Ríos, J. I. 1989. El Paleozoico de Nigüella (nota preliminar). Azara, 1, 35-43.

Valenzuela-Ríos, J. I. \& Botella, H. 2000. Datos preliminares sobre la fauna de vertebrados (Pisces) del Devónico Inferior de Nigüella (Cadenas Ibéricas). Geogaceta, 28, 153-156.

Valenzuela-Ríos, J.I. \& Carls, P. 1996. Identificación estratigráfica del límite regional $\mathrm{d} 2 \mathrm{c} \alpha / \mathrm{d} 2 \mathrm{c} \beta$, Praguiense ("Siegeniense") inferior (Devónico Inferior) en Nigüella (Cordillera Ibérica Oriental, provincia de Zaragoza). Comunicaciones XII Jornadas de Paleontología, Badajoz, 119-120.

Valenzuela-Ríos, J.I., Carls, P. \& Botella, H. 1999. Conodontos, braquiópodos y restos de peces del Devónico Inferior de Nigüella (Cordillera Ibérica). Temas Geológico-Mineros ITGE, 26, 651-652.

Weyant, M. 1967. Représentants de quelques familles d'Ostracodes du Devonien inferieur de la Normandie (Leperditiidae, Bolliidae, Arcyzonidae, Bassleratiidae, Kloenenellidae, Thlipsuridae, incertae familae). Bulletin de la Société Linnéenne de Normandie, (10) 7, 117-141.

Weyant, M. 1980. Les schistes et calcaires de l'Armorique (Devonien inferieur, Massif Armoricain). Mémoires de la Société géologique et minéralogique de Bretagne, 23, 279-287.

Zagora, K. 1968. Ostracoden aus dem Grenzbereich Unter- / Mitteldevon von Ostthüringen. Geologie, 17 (62), 1-91.

Manuscrito recibido: 18 de Diciembre, 2006 Manuscrito aceptado: 11 de Junio, 2007 


\section{FE DE ERRATAS / ERRATUM}

Please make the following correction in the previous issue.

López-Martínez, N., Likius, A., Mackaye, H. T., Vignaud, P. \& Brunet, M. 2007. A new Lagomorph from the Late Miocene of Chad (Central Africa). Revista Española de Paleontología, $22(1), 1-20$.

- The correct figure reference in page 7 line 10 is TM215-01-142 (Figs 3a, 4.3 and 5.1), not TM215-01-142 (Figs $3 \mathrm{a}$ and 5.1).

- The correct species name in table 2 line 2 is Hypolagus gromovi, not Hypolagus igromovi. 